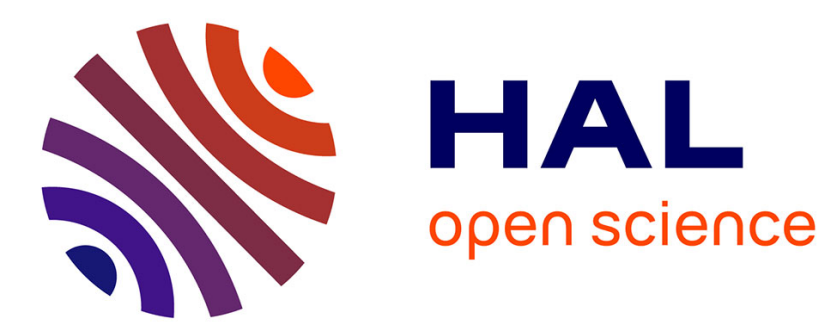

\title{
BRIDGMAN GROWTH AND PROPERTIES OF LuAlO3-Nd3+ LASER CRYSTALS
}

A. Petrosyan

\section{To cite this version:}

A. Petrosyan. BRIDGMAN GROWTH AND PROPERTIES OF LuAlO3-Nd3+ LASER CRYSTALS. Journal de Physique IV Proceedings, 1991, 01 (C7), pp.C7-379-C7-384. 10.1051/jp4:1991799 . jpa00251042

\section{HAL Id: jpa-00251042 https://hal.science/jpa-00251042}

Submitted on 1 Jan 1991

HAL is a multi-disciplinary open access archive for the deposit and dissemination of scientific research documents, whether they are published or not. The documents may come from teaching and research institutions in France or abroad, or from public or private research centers.
L'archive ouverte pluridisciplinaire HAL, est destinée au dépôt et à la diffusion de documents scientifiques de niveau recherche, publiés ou non, émanant des établissements d'enseignement et de recherche français ou étrangers, des laboratoires publics ou privés. 


\title{
BRIDGMAN GROWTH AND PROPERTIES OF LUAIO ${ }_{3}-\mathrm{Nd}^{3+}$ LASER CRYSTALS $^{3}$
}

\author{
A.G. PETROSYAN
}

The Institute for Physical Research, Academy of Sciences of Armenia, Ashtarak-2 378410, USSR

\begin{abstract}
The solidification behavior of $\mathrm{LuAlO}_{3}$ melts in Bridgman geometry is presented. The contribution of different growth parameters to crystallization of single phase LuAlO, are studied. Growth scheme for $\mathrm{LuAlO}_{3}-\mathrm{Nd}^{3+}$ crystals possessing improved laser properties is described.
\end{abstract}

1-Introduction.

LuAlO ${ }_{3}$ (space group $D_{2 h}^{10}-\mathrm{Pbnm}$ ) is the end member of the rhombic rareearth group $\left(\operatorname{LnAlO}_{3}\right.$, where $\mathrm{Ln}=\mathrm{Y}$ or $\mathrm{Ln}$ ion between $\mathrm{Gd}$ and $\left.\mathrm{Lu}\right)$. Five compounds from this group have been so far reported as laser host. crystals, i.e. $\mathrm{YAlO}_{3}, \mathrm{GdAlO}_{3}, \mathrm{ErAlO}_{3},(\mathrm{Er}, \mathrm{Lu}) \mathrm{AlO}_{3}$ and $\mathrm{LuAlO}_{3} / 1 /$, with lasing ions $\mathrm{Pr}^{3+}, \mathrm{Nd}^{3+}, \mathrm{Dy}^{3+}, \mathrm{Ho}^{3+}, \mathrm{Kr}^{3+}$ and $\mathrm{Tm}^{3+} / 1,2 /$. Growth of $\mathrm{LuAlO}_{3}-\mathrm{Nd}^{3+}$ single crystals was first reported in $/ 3 /$. A rod $18 \mathrm{~mm}$ long and $5 \mathrm{~mm}$ in diameter cut from Czochralski grown material lased at $1.0832 \mu \mathrm{m}\left(\mathrm{E}_{\mathrm{thr} .}=8 \mathrm{~J}\right)$ and $1.3437 \mu \mathrm{m}\left(\mathrm{E}_{\mathrm{thr} .}=15 \mathrm{~J}\right)$ at $300 \mathrm{~K} / 4 /$ thus offering generation wavelength shift to long-wave part of the spectrum as compared with $\mathrm{YAlO}_{3}-\mathrm{Nd}^{9+} / 1 /$. Owing to this potential usefulness of $\mathrm{LuAlO}_{3}-\mathrm{Nd}^{3+}$ can be extended if large gize high-quality material is available. In view of results of M.Leduc, L. Shearer on optical polarization of helium atoms, $\mathrm{LuAlO}_{3}-\mathrm{Nd}^{3+}$ based lasers have prospects of application in this field. LuAlO $_{3}$ was prepared also by Bridgman technique /5/. More recently $\mathrm{Nd}^{3+}$ - doped optical quality material was obtained by this technique which reveal substantially better laser per- 
formance /6/ than that reported by Czochralski grown material. This paper summarizes various aspects of Bridgman single crystal growth of $\mathrm{LuAlO}_{9}-\mathrm{Nd}^{3+}$ for laser applications.

2.-Experimental Details.

Vertical Bridgman technique has been used in the present work to study spontaneous solidification behaviour of $\mathrm{LuAlO}_{3}$ melts and growth conditions of laser quality LuAlO $_{3}-\mathrm{Nd}^{3+}$ crystals. The main experimental conditions were the same as described earlier in /5/. Additional variable parameters included cyclic melt overheating then solidification on cooling processes to study statiatical characteristics of freezing end extra crystal annealing at the last stages of crystallization to study $\mathrm{LuAlO}_{3}$ stability to high temperaturas on cooling from the melting point.

3.-Results and Discussion.

The previous results of investigations of $\operatorname{LuAlO}_{3} / 3,5,7-9 /$ show that the main unclearness concerns nucleation and growth mechanism of this phase (it is formed assumingly when crystallization follows some metastable path on cooling of the melts in which the garnet and lutetium oxide phases are the most stable, while LuAlO, has even no stability field in subsolidus region of the phase diagram) and high temperature stability of $\mathrm{LuAlO}_{3}$ upon cooling from the melting point (on heating from the room temperature crystalline LuAlO, readily decomposes at $\geq 1300 \mathrm{C}$, separating garnet and lutetium oxide phases).

Our experiments with melts $1 \mathrm{~cm}^{3}$ in volume have shown that by analogy with some metals the ability of melts to become aupercooled before solidification occurs, depends on the overheating degree and it's length. The supercooling degree increases with increase of the overheating temperature. The overheating length acts in the same direction as the overheating temperature. Note that $\mathrm{LuAlO}_{3}$ phase originate only when solidification occures at high $(\geq 100 \mathrm{~K})$ melt supercoolings with 
respect to the melting point /9/. For comparison, $\mathrm{YAlO}_{3}$ structure is readily formed on cooling of $1: 1$ melts irrespective to the freezing temperature $/ 5 /$. The observed dependence together with results obtained for the melts with garnet composition $/ 5 /$ show that probably no change in coordination number of cations occurs in the melts at high overheating temperatures. More evidently nucleus-size particles of stable phases which are present in initial melts disappear completely during overheating process giving way to simplicity principle $/ 10 /$ to determine solid phase structure. In Bridgman growth the melt is cooled from the bottom so it is here where LuAlog may originate first acting further as a seed crystal. Experiments have shown that after $\mathrm{LuAlO}_{3}$ phase is formed the melt undercooling is being removed due to rapid solidification of the part of the initial melt and replacement of the interface up to the level corresponding to the equilibrium melting point of $\mathrm{LuAlO}_{3}$. This means that solid $\mathrm{LuAlO}_{3}$ which is nucleated at temperatures some $\geq 100 \mathrm{~K}$ below the melting point does not undergo any phase decomposition on heating from nucleation temperature to that close to the melting point. Growth runs which included additional crystal annealing at the cooling stage of the grown material have shown that $\mathrm{LuAlO}_{3}$ conserves transparency with no signs of decomposition up to temperatures some 200-300 $\mathrm{K}$ below the melting point. At lower temperatures of annealing it undergoes complete phase decomposition as it is the case when $\mathrm{LuAlO}_{3}$ is heated from the roon temperature. However the observed behaviour of solid LuAlO, below the melting point cannot be considered as demonstration of thermodynamic stability of this phase in the mentioned temperature region. More evidently, the phase decomposition rate has a complex dependence on the temperature. It may be said that the rate of $\mathrm{Lu}_{3} \mathrm{Al}_{5} \mathrm{O}_{12}$ nucleus formation in solid $\mathrm{LuAlO}_{3}$ has a maximum at some temperature between 1700 and $1300 \mathrm{C}$ while at higher and lower temperatures it is going down. The amount of new phase is dependent on the rate of nucleus formation, their growth velocity and time interval, so at low temperatures the growth velocity, which is diffusion limited, is decreased due to decrease of atoms mobility. The observed stability of solid $\mathrm{LuAlO}_{3}$ at higher temperatures needs additional investigations.

The properties of $\mathrm{LuAlO}_{3}$, revealed in this investigation, show that. crystal growth can be carried out by imploying a scheme presented in Fig.1. It is based on the observed phenomena of conservation of the nucleated crystallization centers of $\mathrm{LuAlO}_{3}$ at temperature increase, i.e. formation of these centers in supercooled melts and their conser-- 
vation during temperature increase close to the melting point.

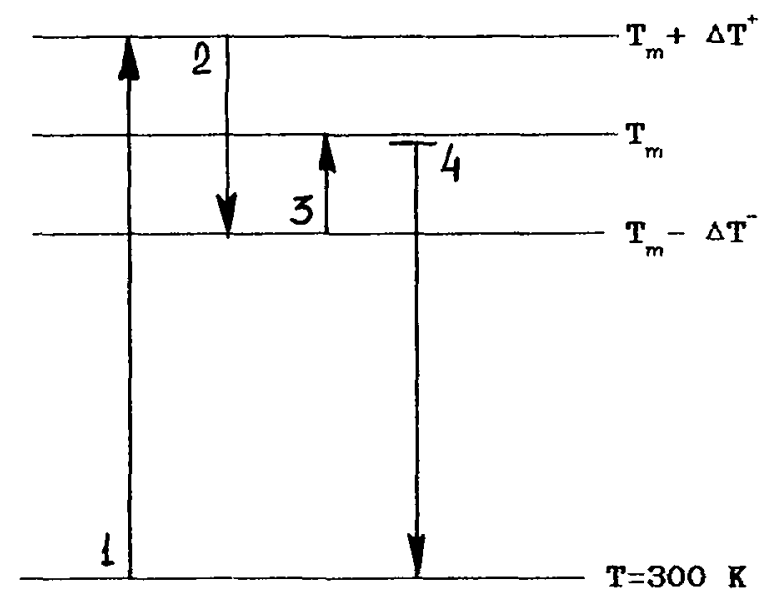

Fig.1. - Growth scheme of LuAlO, single crystals. $T_{m}$-melting point, $\Delta \mathbf{T}^{+}$-melt overheating, $\Delta \mathbf{T}^{-}$-melt supercooling. Arrows indicate the direction of temperature change at each stage of crystallization.

On this base conditions are found which offer crystallization to occur near the equilibrium, which in practice permit to obtain large size optical quality crystals of rhombic $\mathrm{LuAlO}_{3}$, as well as other metastable aluminats of the lanthanide family.

The next point shows that Bridgman technigue is more preferable than Czochralski in view of application to $\mathrm{LuAlO}_{3}$ growth. In Bridgman geometry the melt supercooling necessary to nucleate the metastable phase is self removed, while in Czochralski arrangement an empirical selection of themal conditions is needed.

Spectral and generation experiments with Bridgman grown $\mathrm{LuAlO}_{9}-\mathrm{Nd}^{3+}$ /6/ have shown that these crystals have substantially better laser performance than those reported earlier for Czochralski grown material. In the pulse mode a rod $5 \mathrm{~mm}$ in diameter and $40 \mathrm{~mm}$ long lased at the wavelengths of the main and additional channels of $\mathrm{Nd}^{3+}$ ions at 1.0677 $\left(\mathrm{E}_{\mathrm{thr} .}=0.8 \mathrm{~J}, 77 \mathrm{~K}\right), 1.0675(2 \mathrm{~J}, 300 \mathrm{~K}), 1.3429(1.5 \mathrm{~J}, 100 \mathrm{~K})$ and $1.3437 \mathrm{mu}(3 \mathrm{~J}, 300 \mathrm{~K})$. 
4. - Conclusions.

The melt solidification properties of metastable $\mathrm{LuAlO}_{3}$ are studied. Basing on obtained experimental results a growth scheme of $\mathrm{LuAlO}_{3}-\mathrm{Nd}^{3+}$ crystals using Bridgman technique is proposed, which permits crystallization to occur near to the equilibrium and to obtain large size material of improved optical and laser guality.

The author wishes to thank Professor A.A.Raminskii who initiated this investigation and Professor A.A.Chernov for discussions around unusual properties of this crystalline phase. The $X$-ray phase identification has been performed by Dr. G.O.Shirinyan.

References

/1/ RAMINSKII,A.A. et al. Physics and Spectroscopy of Laser Crystalls, Moscow, Nauka, 1986.

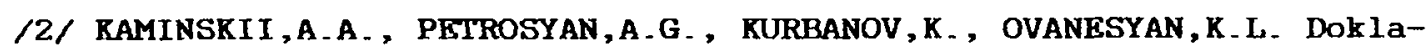
dy AN SSSR 295 (1987) 586.

/3/ IVANOV, A.O., MOROZOVA,L.G., MOCHALOV, I.V., FEOEILOV, P.P. Optika i spektroskopiya 32 (1975) 405 .

/4/ RAMINSKII,A.A., IVANOV,A.O., SARKISOV,S.E. et al JETF 71 (1976) 984.

/5/ PETROSYAN,A_G., SHIRINYAN,G_O_, OVANESYAN, K. L., KUZANYAN,A.S. J.Crystal Growth 52 (1981) 556.

/6/ KAMINSKII,A.A., PETROSYAN, A.G., MARKOSYAN,A.A. Izv.AN SSSR, Ser. Neorgan. Mater. 26 (1990) 1781 .

/7/ SHIRVINSKAYA, A.K., POPOVA,V.F. Dokladi AN SSSR 233 (1977) 1110

/8/ BONDAR, I.A., SHIRVINSKAYA,A.R., POPOVA,V.F. et al Dokladi AN SSSR 246 (1979) 1132 
/9/ PETROSYAN,A.G., SHIRINYAN,G.O., OVANESYAN, K.L., RUZANYAN,A.S. Abstr. Intern. Conf . Crystal Growth, Moscow, vol .3 (1980) 119.

$/ 10 /$ COCKAYNB, B., LRNT, B. J.Cryotal Growth 46 (1979) 371. 